\title{
SELF-DISCLOSURE DITINJAU DARI TIPE KEPRIBADIAN DAN SELF-ESTEEM PADA REMAJA PENGGUNA MEDIASOSIAL
}

Achmad Zulkifli Adnan, Fina Hidayati Universitas Islam Negeri Maulana Malik Ibrahim Malang

E-mail: achmadza8@gmail.com

\begin{abstract}
ABSTRAK, Manusia dalam hidupnya selalu bergantung kepada manusia lain. Manusia selalu butuh berkomunikasi dengan manusia lain. Seiring dengan modernnya zaman, kini komunikasi manusia semakin kreatif dengan adanya media sosial online. Penelitian ini bertujuan untuk menjelaskan adanya pengaruh yang signifikan antara tipe kepribadian dan self-esteem terhadap self-disclosure pada remaja pengguna media sosial. Penelitian ini menggunakan pendekatan kuantitatif yang diukur menggunakan tiga skala yaitu Eysenck Personality Inventory (EPI), Self-esteem Coppersmith, dan Self-disclosure Scale. Responden penelitian adalah 205 remaja yang diambil dengan teknik purposive sampling. Hasil penelitian menunjukkan bahwa terdapat pengaruh Tipe kepribadian dan self-esteem terhadap Self-disclosure., Tipe kepribadian dan self-esteem mempengaruhi self-disclosure sebesar 56,3\%. Tipe kepribadian memberikan sumbangan sebanyak $1,5 \%$ dan self-esteem sebanyak $54,7 \%$ terhadap self-disclosure.
\end{abstract}

Kata kunci: Remaja, Self-Disclosure, Self-esteem, Tipe Kepribadian.

\section{SELF-DISCLOSURE VIEWED FROM PERSONALITY TYPES AND SELF-ESTEEM IN ADOLESCENT USERS OF SOCIAL MEDIA}

\begin{abstract}
Humans always depend on other human beings. Humans always need to communicate with other human beings. Along with the modern era, is now increasingly creative human communication with the online social media. This study aims to explain the existence of a significant influence between personality type and self-esteem on self-disclosure in adolescent users of social media. This study uses quantitative approaches measured using three scales: Eysenck Personality Inventory (EPI), Self-esteem Coppersmith, and Self-disclosure Scale. The respondents are 205 teenagers taken with purposive sampling technique. The results showed that there is influence Personality type and self-esteem to Self-disclosure. Personality type and self-esteem affect to self-disclosure by $56.3 \%$. Personality types contribute as much as $1.5 \%$ and self- esteem of $54.7 \%$ to self-disclosure.
\end{abstract}

Keywords: Adolescent, Self-disclosure, Self-esteem, Personality Type

\section{PENDAHULUAN}

Manusia dalam hidupnya perlu berinteraksi dengan yang lain. Hubungan antarpribadi memainkan peran penting dalam pembentukan sebuah kehidupan. Melalui komunikasi yang baik, indvidu diharapkan mempunyai hubungan sosial yang baik. Manusia selalu bergantung kepada orang lain dalam perasaan, pemahaman, informasi, dukungan dan berbagai bentuk komunikasi yang mempengaruhi citra diri seseorang dan membantu mengenali harapan-harapan orang lain. Proses penyampaian diri ini kepada orang lain oleh Jourard disebut sebagai pengungkapan diri atau self-disclosure (dalam Sari dkk, 2006). Di era yang serba digital ini menyebabkan tingginya tuntutan manusia terhadap kebutuhan informasi. Semua dapat diakses dengan cepat sehingga dapat jarak ruang dan waktu menjadi lebih dekat dan cepat. Semua orang dapat dengan mudah mengakses informasi yang penting tentang fenomena kejadian diseluruh belahan dunia, tanpa harus pergi ke tempat tersebut. Padahal untuk mencapai tempat tersebut memerlukan waktu yang berjam-jam, namun dengan adanya seperangkat komputer yang terkoneksi dengan internet, seseorang dapat dengan mudah mengakses informasi penting dalam waktu yang singkat (Kusumaningtyas, 2010).
Internet adalah sebuah pintu masuk untuk menelusuri informasi diseluruh dunia. Bermacammacam informasi dapat kita dapatkan melalui internet. Seiring dengan perkembangan zaman, internet mampu mencetuskan suatu jaringan baru yang biasa dikenal dengan sebutan media sosial (Setyani, dkk, 2013). Data yang dilansir secara global oleh youthmanual.com pada tahun 2017, total dari 2,9 miliyar atau 39\% dari jumlah penduduk di dunia merupakan pengguna media sosial, sedangkan 2,6 miliyar atau 36\% dari jumlah penduduk di dunia mengakses media sosial melalui telepon genggam.

Dalam kehidupan nyata, tingkah laku manusia bisa diketahui dan dikenali apa adanya. Lain halnya dengan kehidupan masyarakat di dunia maya yang merupakan suatu kehidupan manusia yang tidak bisa secara langsung diindera melalui penginderaan manusia, tetapi hanya mampu dirasakan dan disaksikan seperti halnya sebuah realitas. Orang yang biasanya di dunia nyata terlihat baik-baik saja, bisa mengekspresikan emosinya di dunia maya melalui fasilitas media sosial berupa update status. Hakikatnya setiap orang mengadakan orientasi terhadap dunia sekitarnya, tergantung karakteristik atau tipe kepribadiannya sehingga memungkinkan orientasi orang yang satu dengan orang lainnya berbeda. Orientasi manusia ada yang memiliki arah keluar 
(ekstrovert) dan ke dalam (introvert) (Kusumaningtyas, 2010). Ditinjau dari tipe kepribadian, ada dua tipe kepribadian dalam menggambarkan pengguna internet. Eysenck mengkategorikan manusia berdasarkan dua tipe kepribadian, yaitu tipe kepribadian introvert dan tipe kepribadian ekstrovert (Suryabrata, 2008). Orangorang yang introvert memperlihatkan kecenderungan yang tertutup dan subjektif pada dunianya. Sebaliknya, orang yang mempunyai tipe kepribadian ekstrove,

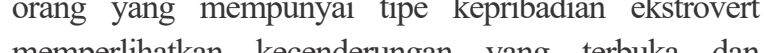

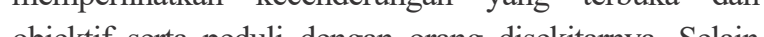

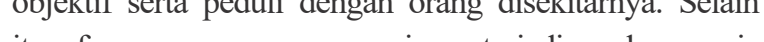
itu, fenoma yang sama juga terjadi pada remaja yaitu merasa ingin dinilai oleh orang lain. Pada saat remaja harga diri (self-esteem) mereka mengalami penurunan
dan akan kembali naik pada saat dewasa awal (Santrock, dan akan kembali naik pada saat dewasa awal (Santrock,
2014). Kekhawatiran untuk membuka diri kepada orang lain berkaitan dengan resiko yang akan diterima, misalnya bila kelemahannya diketahui oleh orang lain. Hambatan dalam mengungkapkan diri juga berkaitan dengan rasa aman dan percaya pada diri sendiri. Rasa aman akan tercapai bila seseorang percaya dan memiliki pikiran positif bahwa orang lain tidak akan merendahkan dirinya setelah mengetahui keadaan yang sebenarnya. Peniluin positif posif keridu menting yang positf tce dop dis berkaitan dengan harga diri (sef-esteem), yaitu evaluasi diri yang dibuat individu terhadap dirinya dalam rentang positif sampai negatif (Baron dan Byrne, 2004). Raven dan Rubin (1983) menjelaskan bahwa dalam prosesnya, self-disclosure pada individu yang terlibat mempunyai kecenderungan menyertakan atau mengikuti norma resiprok (timbal balik) apabila seseorang menceritakan suatu hal yang bersifar privasi, kita akan cenderung memberikan respon yang sepadan. Pada dasarnya kita mengharap orang lain yang memperlakukan kita sam dengan yang kita memperlakukan orang lain.

Dari beberapa uraian diatas, peneliti tertarik untuk melakukan penelitian tentang self-disclosure ditinjau dari tipe kepribadian dan Self-esteem pada remaja penggun media sosial.

\section{Self-Disclosure}

Secara etimologi, self berarti diri sendiri, closure diartikan sebagai penutupan, pengakhiran, sehingga disclosure berarti terbuka atau keterbukaan. Denga demikian, self-disclosure adalah pengungkapan diri atau keterbukaan diri. Devito (2011) menyatakan bahwa self-disclosure atau keterbukaan diri adalah jenis komunikasi dimana individu mengungkapkan informa tentang dirinya yang biasanya disembunyikan atau tide dicertakn kepad orng bin. Morton (darm

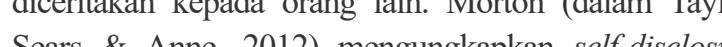

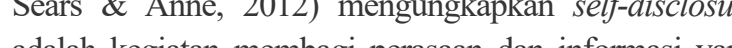
akrab do deskriptif dan evaluatif. Keterbukaan diri deskriptif adalah kegiatan menerangkan berbagai fakta mengenai diri individu yang belum diketahui oleh orang lai yang berada dilingkungan sekitarnya. Keterbukaan dir evaluatif adalah kegiatan mengungkapkan pendapa atau perasaan individu seperti mengungkapkan perasaa mengenai orang-orang yang disukai ataupun tidak disukai. Dari beberapa pengertian diatas self-disclosure adalah kegiatan mengungkapkan informasi kepad rang hin yang berhubungan dongen infori orang

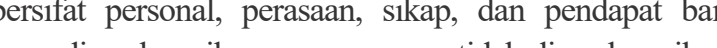
yang disembunyikan maupun yang tidak disembunyikan, non untuk membagi informasi tentang dirinya yang berup perilaku dan kualitas dirinya tersebut.

\section{Tipe Kepribadian}

Secara umum kepribadian (personality) suatu pola watak yang relatif permanen, dan sebuah karakter unik yang memberikan konsistensi sekaligus individualis bag perilaku seseorang (Feist \& Feist, 2010). Allport (dalam Suryabrata, 2008) merumuskan kepribadian sebaga suatu organisasi yang dinamis dari sistem psikofisik individu yang menentukan tingkh laku dan pemikira individu lingk (n) penare keseluruha pola perilaku, baik yang aktual maupun yang potensia dari organisme yang ditentukan oleh pembawaan dan lingkungan. Jung (dalam Feist \& Feist, 2010 mengkategorikan tipe kepribadian menjadi dua tipe yakni introvert dan ekstrovert. Orang-orang dengan kecenderungan introvert selalu mendengarkan perasaan batinnya, dan mempunyai persepsi sendiri. Merek tetap bersentuhan dengan dunia luar, namun mereka lebih selektif untuk memilih dunia mana yang tepat dan didasarkan pada pandangan subjektif mereka. Sedangka orang-orang yang ekstrovert lebih banyak dipengavih an dipengaruh merekn sendi. - Mereka cenderung fokus kepada sika

\section{Self-Esteem}

Istilah self-esteem yang dalam bahasa indonesia disebut dengan harga diri. Baron dan Byrne (dalan Geldard, 2011) menyebut harga diri sebagai penilaia terhadap diri sendiri yang dibuat individu dan dipengaruhi oleh karakteristik yang dimiliki oleh orang lain dalan menjadi pembanding. Branden (dalam Suhron, 2016) mengungkapkan bahwa self-esteem merupakan evaluas positif dan negatif tentang diri sendiri yang dimilik seseorang Evaluasi ini memperlin yom bagiman individu menilai dirinya sendiri dan diakui bagaiman ke tidakny Coperolehny Copers (d terdapat empat aspek dalam Self-esteem individu.
Aspek-aspek tersebut yaitu kekuatan, keberartian, kebajikan, kompetensi. Kekuatan menunjukan pada adanya kemampuan seseorang untuk dapat mengatur dan mengontrol tingkah laku dan mendapat pengakuan atas tingkah laku tersebut dari orang lain. Keberartian menunjukan pada kepedulian, perhatian, afeksi dan ekspresi cinta yang di terima oleh seseorang dari orang lain yang menunjukkan adanya penerimaan dan popularitas individu dari lingkungan sosial. Kebajikan menunjukan suatu ketatan untuk mengikuti standar morl dan suan ketik an etika ang di hinderi dan yang has dik laku yang

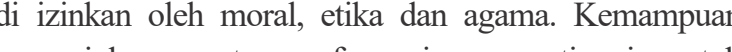
menunjukan suatu performasi yang tinggi untuk memenuhi kebutuhan dan mencapai prestasi (need of achievement) dimana level dan tugas-tugas tersebu tergantung pada variasi usia seseorang. Berdasarkan beberapa pendapat diatas, bahwa self-esteem adalah penilaian individu terhadap kehormatan diri, melalui sikap terhadap dirinya sendiri yang bersifat implisit atau tersirat, tidak diverbalisasikan dan menggambarkan sejauh mana individu tersebut menilai dirinya sebagai orang yang memiliki kemampuan, keberartion, berharga, dan kompeten.

\section{METODE PENELITIAN}

Penelitian ini menggunakan pendekatan kuantitatif, yakni suatu proses menemukan pengetahuan yang menggunakan data berupa angka sebagai ala menganalisis keterangan mengenai apa yang ingin diketahui (Kasiram, 2008). Populasi dari penelitian in adalah remaja usia 15-18 tahun, dan telah memakai media sosial. Adapun karakteristik sampel pada penelitian ini adalah remaja dengan usia 15-18 tahun, mempunyai media sosial dan setidaknya pernah mengakses media sosial untuk berkomunikasi Teknik yang digun lam penelitin ini add teknik non-pobaka sampling yaitu purposive 205 repola

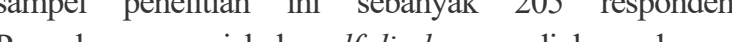
Pengukuran variabel sef-disclosure diukur dengan menggunakan kuesionor yang diadaptasi dari alat ukur self-disclosure Magno, dkk (2008). Nilai reliabilitas pada alat ukur ini adalah 0,737. Adapun komponen yang diukur meliputi, emotional state, interpersonal relationship, personal matters, problem, religion, sex, teste, thoughts, work / accomplishment. Pengukuran variabel self-esteem diukur dengan menggunakan kuesioner yang telah diadaptasi dari alat ukur self-esteem Copersmith (1967). Nilai reliabilitas pada alat ukur ini adalah 0.789. Adapun komponen yang diukur meliputi, power significance, virtue dan competence. Sed pengukuran tipe kepribadian ini menggunakan skala baku dari Eysenck yakni Eysenck Personality Inventory. Alat ukur ini dikembangkan oleh Eysenck berdasarkan teori trait (Eysenck dan Wilson dalam Velicer, 1978). Adapun dalam penelitian ini mengkategorikan tipe kepribadian ekstrovert dan introvert. Komponen yang diukur dalam alat ukur ini meliputi, Activity, Sociability, Rist Taking, Impulsivenes, Expressiveness, Reflectivenes, dan Responsibility. Analisis data yang digunakan pad penelitian ini adalah Analisis Regresi Berganda dengan bantuan SPSS 16. Namun sebelum itu, peneliti terlebi dahulu dianalisis deskriptif, uji normalitas dan uji linearitas.

\section{HASILDAN PEMBAHASAN}

Tabel 1. Gambaran kategorisasi self-discloseure pad

Remaja

\begin{tabular}{|c|c|c|c|}
\hline Kategori & Range & Frekuensi & Prosentase \\
\hline Tinggi & $61-80$ & 44 & $21,46 \%$ \\
\hline Sedang & $40-60$ & 161 & $78,54 \%$ \\
\hline Rendah & $20-39$ & 0 & 0 \\
\hline
\end{tabular}

\section{Tabel 2. Gambaran kategorisasi self-esteem}

Tabel 2. Gambaran kategorisasi self-esteem
\begin{tabular}{|c|c|c|c|}
\hline Kategori & Range & Frekuensi & Prosentase \\
\hline Tinggi & $76-100$ & 111 & $54,15 \%$ \\
\hline Sedang & $50-75$ & 94 & $45,85 \%$ \\
\hline Rendah & $25-49$ & 0 & 0 \\
\hline Jumlah & 205 & $100 \%$ \\
\hline
\end{tabular}

Tabel 3. Kecendrungan Tipe Kepribadian

\begin{tabular}{|c|c|c|c|}
\hline $\begin{array}{c}\text { Tipe } \\
\text { Kepribadian }\end{array}$ & Range & Frekuensi & Prosentase \\
\hline Ekstrovert & $15-24$ & 138 & $67,32 \%$ \\
\hline Introvert & $0-11$ & 67 & $32,68 \%$ \\
\hline \multicolumn{2}{|c|}{ Jumlah } & 205 & $100 \%$ \\
\hline
\end{tabular}

apatkan hasil sebagai berikut.

Tabel 1 menunjukkan sebanyak 161 responden (78,54\%) menunjukkan nilai self-disclosure yang sedang dan 44 responden $(21,46 \%)$ menunjukkan nila self- disclosure yang tinggi. Individu yang memilik self-disclosure tinggi adalah mereka yang dapa mengungkapkan dirinya. Baik itu secara langsung ataupun dengan media sosial. Devito (2011) menjelaskan keterbukaan diri dapat berupa banyak topik sepert informasi perilaku, sikap perasaan, keinginan, motivas dan ide yang sesui den terdapat di dalam diri orang yang bersanglutan Seperti pada salah diri orang yeterbatan "s

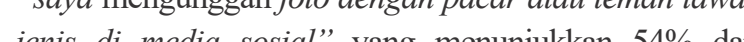
jenis di media sosial" yang menunjukkan $54 \%$ dari remaja pernah melakukannya di media sosial dan $17 \%$ (dalo (dalam Taylor, Sears \& Anne, 2012) mengungkapkan bahwa pengungkapan diri termasuk dalam kegiata yang bersifat evaluatif, yakni kegiatan mengungkapkan mengenai orang-orang yang disukai atau yang tidak disukai. Berdasarkan tabel 2, menunjukkan mayoritas 
responden memiliki skor self-esteem yang tinggi yaitu sebanyak 111 responden $(54,15 \%)$. Sementara 94 responden lainnya $(45,85 \%)$ menunjukkan skor selfesteem yang sedang. Myers (2012) menjelaskan orang yang memiliki self-esteem yang tinggi dapat memiliki rasa menghargai dirinya dengan baik, dapat menghormati dirinya, tidak menganggap dirinya sempurna atau lebih baik dari orang lain tetapi juga tidak lebih buruk. Orang yang memiliki selfesteem tingoi juga mempunyai sikap

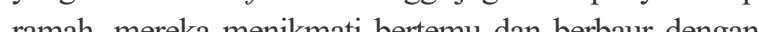
orang yang bour secen umum morka memiliki ma pues pada mereka jug dopt merim perba kyes (2012) menambahk bawa renda

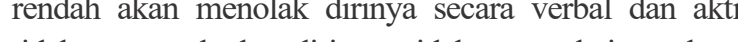
tidak puas terhadap dirinya, tidak menyukai gambara dirinya dan menginginkan berbeda namun tidak yak akan mampu mengubahnya Pada tabel 3 di atas, diketahui dari 205 responden remaja yang memiliki kecenderunga pada kepribadian ekstrovert sebanyak 138 remaja dan yang memiliki kecenderungan pada kepribadian introvert sebanyak 67 remaja. Adapun jika diprosentasek menjadi remaja dengan kecenderuang $67,32 \%$ den 67, 32,68\% . Keplo merupana Jung (dalam Alwsol, 2016) bependapat bahwa oran yang memiliki sikap ekstraversi mengarahkan priba pada pengalaman obyektif, memusatkan perhatianny ke dunia luar, cenderung berinteraksi dengan orang yang ada disekitarnya, aktif dan ramah. Sedangkan orang yang memiliki sikap intraversi mengarahkan pribadi ke pengalaman yang subjektif, memusatkan diri pada duni dalam dan privat di mana realita hadir dalam bentuk amatan, cenderung pendiam, umumnya orang ini senang introspektif dan senang dengan hidup mereka sendin.

\section{Tabel 4. Hasil Uji Regresi Berganda}

\begin{tabular}{|c|c|c|c|}
\hline $\begin{array}{c}\text { Devendent } \\
\text { Variable }\end{array}$ & Predictors & Beta & Sig \\
\hline \multirow{2}{*}{ Self disclosure } & Tipe Kepribadian & $-0,101$ & 0,031 \\
\cline { 2 - 4 } & Self-esteem & 0.740 & 0,000 \\
\hline
\end{tabular}

Tabel 5. Hasil Uji beda tipe kepribadian dengan selfdisclosure

\begin{tabular}{|c|c|c|c|c|c|c|}
\hline \begin{tabular}{|c|c|} 
Dev- \\
endent \\
Vari- \\
able
\end{tabular} & \begin{tabular}{|c} 
Tipe \\
Ke- \\
priba- \\
dian
\end{tabular} & $\mathrm{N}$ & Mean & $\begin{array}{l}\text { t-test for } \\
\text { Equality } \\
\text { of means }\end{array}$ & $\mathrm{F}$ & $\mathrm{Sig}$ \\
\hline \begin{tabular}{|l|l} 
Self- \\
Dis-
\end{tabular} & \begin{tabular}{|l}
$\begin{array}{l}\text { Ekstro- } \\
\text { vert }\end{array}$ \\
vstro- \\
\end{tabular} & 67 & 56.9701 & \multirow{2}{*}{1,801} & \multirow{2}{*}{0,414} & \multirow{2}{*}{0,73} \\
\hline $\begin{array}{l}\text { clo- } \\
\text { sure }\end{array}$ & \begin{tabular}{|l|}
$\begin{array}{l}\text { Intro- } \\
\text { vert }\end{array}$ \\
\end{tabular} & 138 & 55,4203 & & & \\
\hline
\end{tabular}

Pada tabel 4 diatas menunjukkan bahwa variable tipe kepribadian memberikan kontribusi yang lebih renda ( $\beta=-0,101)$ dibanding dengan self-esteem $(\beta=0,740$.
Variabel tipe kepribadian memiliki pengaruh signifikan terhadap self-disclosure dengan nilai signifikansi 0,03 $(p<0,05)$. Hal ini berarti dalam penelitian ini terbuk menyatakan terdapat pengaruh antara tipe kepribadian terhadap self-disclosure. Sejalan dengan tipe kepribadian, self-esteem juga mempengaruhi secara signifikan dengan nilai signifikansi adalah $0,000 \quad(p<0,05)$. Hal ini berarti masing-masing variabel yang menyatakan terdap pengrub pengaruh antara tipe kepribadian dan self-esteem terhadap self-disclosure. Sedangkan presentase pengaruh tip kepribadian terhadap self-disclosure sebesar 1,5\% dan self-esteem mempengaruhi sebesar $54,7 \%$. Hasil analis tambahan ditabel 5 menunjukkan nilai signifikansinya adalah $0,73(p>0,05)$. Hal ini menyatakan bahwa tidak ada perbedaan pada self-disclosure antara tipe kepribadian ekstrovert dan introvert. Dilihat dari nilai rata-rata, skor dari kedua tipe kepribadian juga perbedaannya tidak terlalu signifikan. Hasil pada analisis pada tabel 4 mendukung teori yang dikemukakan oleh Devito (dalam Masturah, 2013) yang menyebutkan salah satu faktor yang mempengaruhi self-disclosure adalah kepribadian. Orang yang pandai bergaul (orang yang memiliki jiw sociable) cenderung mudah melakukan self-disclosure sociable) cenderung mudah melakukan self-disclosure Rossen (2008) menyatakan bahwa seseorang meras aman meng in orang lain di media sosial. Dengan demikian remaja yan memiliki self-disclosure tinggi akan merasa nyaman dan aman untuk mengungkapkan diri di dunia maya mengena keterbukaan dirinya tentang hal-hal yang personal dan impersonal. Sebaliknya seseorang yang memiliki selfdisclosure rendah cenderung akan lebih berhati-hat dalam mengungkapkan diri di media sosial, mereka hanya akan mengungkapakan diri tentang hal- hal yang bersifa impersonal atau tentang ha-hal tertentu saja. Sehingg mereka akan menyaring terlebih dahulu informasiinformasi yang akan diungkapkan. Mereka cenderun tidak menoungkapkan hal-hal yang dianggap tabu, aib, tidak mengngkapkan hal-hal yang dianggap tabu, aib, akan dibuka dan mungkin ditutupi karena timbul perasaan akan takn nain. Remaja yan memiliki kecenderungan kepribadian ekstrovert, merek akan nyaman mengungkapkan apa saja baik yang personal maupun impersonal di media sosial, masalahmasalah pribadinya, hubungan percintaannya dengan orang lain. Remaja yang memiliki self-disclosure tingg akan merasa nyaman mengunggah foto/video, chatting, berbagi berkomentar di media sosial, membuat ata mengunggah status tentang hal-hal pribadi seperti curahan hati, masalah perasaan mereka. Correa. (dalam Moore, 2012), menjelaskan ekstraversi memiliki hubungan positif dengan penggunaan jejaring sosial. Kebanyakan orang dengan sikap ekstraversi ini mempunyai banyak teman media sosial dan lebih mungkin mengunggah kegiatannya dalam sebuah status di media sosialnya. Temuan ini dalam sebuah status di media sosialnya. Temuan in
menunjukkan bahwa ekstraversi lebih dekat terkait dengan pengungkapan pribadi dari aktivitas saat ini dan pemikiran tentang minat mereka, juga dari teman-teman yang sama ekstraversinya. Sebenarnya adanya media sosial tidak hanya diperuntukkan untuk orang dengan kepribadian tertentu saja. Namun lebih dari itu, merekalah yang dengan bijak untuk menggunakan media sosial ke arah yang bagaimana. Jejaring sosial yang ada secara luas ditargetkan untuk semua individu yang ingin berinteraksi dan terlibat dalam hubungan interpersonal (Harbaugh, 2010). Karen ito tidak hana orang elstrovet sija yang bise me Kaja yang bisa menkan tidak menutup kemungkinan orang dengan kecenderungan introvert juga dapa terbuka di media sosial. Fasilitas media sosial sebenarnya dapat dikatakan memberikan introvert sebuah kesempatan untuk menjalin hubungan dengan orang lain. Tidak hanya itu, hal ini juga memungkinkan ekstrovert mampu untuk tetap terhubung dengan dunia maya pada saat-saat mereka sedang sendiri di kehidupan dunia nyata. Seperti yang dijelaskan oleh pakar psikologi forensik, Reza Indragiri Amriel yang mengungkapkan bahwa seseorang yang memiliki karakter introvert atau pendiam bisa terkadang lebih banyak berbicara di media sosial. Hal ini dikarenakan resiko personal yang didpat lebih sedikit Sedangkan untuk orangyang didapa lebh secling orangkeseharian mercka kesen. dengan al ma medrang bagi mereka untuk berekspresi. Oleh karena itu orang ekstrovert merasa terfasilitasi (Tempo.com, 26 desember 2011). Hal yang serupa juga dijelaskan oleh Tosun, dkk (dalam Harbaugh, 2010) yang menjelaskan introvert juga menggunakan media sosial sebagai pengganti atau alternatif untuk komunikasi interpersonal tatap muka. Ini menunjukkan introvert yang mengalami kesulitan dalam interaksi tatap muka atau yang juga menghindari berkomunikasi tatap muka lebih memilih interaksi online. Sama halnya dengan ekstrovert, introvert hanya butuh ruang saja untuk menghindari kekurangannya dalam Di sisi Dissin moda. Remaja yang merasa tidak yakin dengan diri sendiri tidak akan bersedia memberikan informasi pribadinya kepada orang lain. Remaja dengan self-esteem rendah akan kurang mengungkapkan atau membuka dirinya secara langsung. Hal ini terjadi karena remaja merasa terancan adanya bahaya jika mengungkapakan dirinya secara tatap muka. Mereka akan merasakan hal seperti, takut diejek atau ditolak oleh lingungannya. Karena orang dengan self-esteem rendah mengungkapkan diri kurang daripada orang dengan self-esteem yang tinggi. Adanya kesempatan untuk berkomunikasi dengan orang lain di media sosial, mungkin mungkin sangat bentarga bagi mereka (Forest, 2012). Hal lain yang pellu diwaspadai adalah apabila remaja

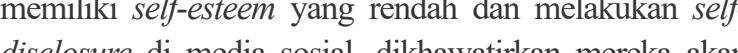
aisclosure di media sosial, dikhawatirkan mereka akan
terbuka juga dengan hal-hal yang negatif mengenai dirinya. Hal ini dikarenakan banyak diantara media sosial yang memiliki jangkauan yang sangat luas. Artinya tanpa kita harus berteman, kita bisa melihat kondisi dari oran yang mempunyai akun tersebut. Misalkan saja Facebook Instagram dan lain sebagainya. Tanpa kita harus mengena satu sama lain, kita bisa mengetahui keadaan seseorang tersebut melalui status yang dibuatnya. Hal ini bisa menjadi boomerang bagi mereka jika melakukan hal yan negatif di media sosial. Resiko dari keterbukaan diri

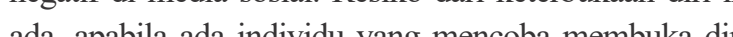
nanu leperan selfesteem yong mengungkapkan kekurangan ada diri mereka (Baumeister, dkk, dalam Forest, 2012).

\section{SIMPULAN}

Hasil penelitian ini secara umum menunjukkan bahwa terdapat pengaruh tipe kepribadian dan selfesteem terhadap self-disclosure pada remaja pengoun media sosial. Remaja dengan kecenderungan kepribadi ekstrovert dapat mengounakn median sosil di ibeadia deng les di intern deng jociable yan di media sosial daripada bertatap muka karena kurang mampu bergaul dan berkomunikasi tatap muka dunia nyatanya. Remaja dengan self-esteem rendah mengalami kesulitan dalam menceritakan dirinya yan sebenarnya. Karena orang dengan self-esteem rendah mengungkapkan diri kurang daripada orang dengan harga diri yang tinggi. Dengan adanya kesempata untuk berkomunikasi di media sosial mungkin sanga berharga bagi mereka. Individu dengan kecenderungan ekstrovert maupun introvert untuk lebih bijaksana dalam melakukan pengungkapan dirinya dimedia sosial dengan memperhatikan kecenderungan self-disclosure berdasarkan kepribadian mereka. Begitu juga untuk mengembangkan dan mengoptimalkan self-esteen dengan self-disclosure dalam melakukan komunikasi. Sedang bagi peneliti selanjutnya, untuk meningkatkan kualitas penelitiannya lebih lanjut. Peneliti dapa menambah variabel lain seperti kontrol diri, kepribadia big five personality, dan sebagainya untuk menjelaskan dipenelitian mendatang mengenai faktor yang mempengaruh self-disclosure, mengingat di era global ke depan past akan berkembang lagi fitur dari media sosial.

\section{DAFTAR PUSTAKA}

Adnan, Achmad Zulkiffi, Mauliawati Fatimah, Munaela Zufia (2016). Pengaruh Dukungan Sosial Terhadap Selfesteem Remaja Desa Wonoayu Kecamatan Wajak Jurnal Psikoislamika. 13(2)

Alwisol. (2009). Psikologi Kepribadian Edisi Revisi. Malang

UMM Press. Baron, Robert A. \& Byrne, Donn 
(2004). Psikologi Sosial. Jakarta: Erlangga DeVito, J. A. (2011). Komunikasi antar manusia. Jakarta: Professional books.

Feist, Jess dan Feist, Gregory. (2010). Teori Kepribadian. Buku 2. Jakarta: Salemba Humanika

Forest, Amanda. L, Joanne V. Wood. (2012). When Social Networking Is Not Working: Individuals With Low Self-Esteem Recognize but Do Not Reap the Benefits of Self-Disclosure on Facebook. Psychological Science 23(3) 295-302.

Geldard, K \& Geldard D. (2011). Konseling Remaja. Yogyakarta:Pustaka Pelajar.

Harbaugh, Erin Ryan. (2010). The Effect of Personality Styles (Level of Introversion-Extroversion) on Social Media Use. The Elon. Journal of Undergraduate Research in Communications 1(2)

Kasiram, Moh. (2008). Metode Penelitian. Malang: UIN Malang Press.

Kusumaningtyas, R.D. (2010). Peran Media Sosial Online (Facebook) Sebagai Saluran Self- Dislcosure Remaja Putri Di Surabaya. Surabaya: Fakultas Ilmu Sosial dan Politik.

Magno, Carlo, Sherwin CuasonChristine Figueroa. (2008). The Development of the Self- disclosure Scale. Retrieved from http://www. scribd.com, 17 Maret 2018

Masruroh, Lailatul. (2016). Pengaruh pola asuh dan harga diri terhadap penyesuaian sosial mahasiswa baru. UIN MALIKI Malang. Skripsi.

Moore, Kelly, James C. McElroy. (2012). The Influence of personality on Facebook usage, wall postings,and regret. Computers in Human Behavior. 28, 267-274
Myers, G. E \& Michelle, T.M. (1992). Dinamia Komunikasi Manusia : A Laboratory Approach. New York : Mc. Graw - Hill Inc.

Raven, B.H dan Rubin J.Z. (1983). Social Psychology second edition. John Wiley and Sons. Inc.

Rosen, D. Larry, Cheever, A. Nancy, Cummings, Cheyenne \& Felt, Julie. (2008). The impact of emotionality and selfdisclosure on online dating versus traditional dating. Computers In Human Behavior. No 24. 2124 -2157

Sari, R.P., Rejeki, T.A., \& Mujab, Achmad. (2006).Pengungkapan Diri Mahasiswa Tahun Pertama Universitas Diponegoro ditinjau dari Jenis Kelamin dan Harga Diri. Jurnal Psikologi UniversitasDiponegoro, 3(2) Santrock, John. (2014). Adolescence, Perkembangan Remaja. Jakarta: Penerbit Erlangga.

Suhron, Muhammad. (2016). Asuhan Keperawatan Konsep Diri : Self Esteem. Ponorogo: Unmuh Ponorogo Press.

Suryabrata, Sumadi. (2008). Psikologi Kepribadian. Jakarta: PT. Raja Grafindo Persada.

Taylor, E. Shelley, L. A. Peplau, D. O. Sears. (2012). Psikologi Sosial edisi 12. Jakarta: Kencana.

Tempo.co. (2011, 26 Desember) Si Pendiam Lebih Cerewet Di Media Sosial. Diakses 2 April 2018, dari http:// gaya.tempo.co

Velicer, Wayne F. and John F. Stevenson. (1978). Applied Psychological Measurement. Vol. 2, 293-304.

Vorn, Ronald J.J, Piet A.M. Kommers. (2013). Social Media And Higher Education: Introversion And Collaborative Learning From The Student's Perspective. Int. J. Social Media and Interactive Learning Environments, 1(1), 59-73. 